University of Nebraska - Lincoln

DigitalCommons@University of Nebraska - Lincoln

\title{
Multiplex real-time PCR for detection, identification and quantification of 'Candidatus Liberibacter solanacearum' in potato plants with zebra chip
}

\author{
Wenbin Li \\ USDA-APHIS-PPQ-CPHST \\ Jorge A. Abad \\ USDA-APHIS-PPQ-PHP-PSPI \\ Ronald D. French-Monar \\ Texas A\&M \\ John Rascoe \\ USDA-APHIS-PPQ-PHP \\ Aimin Wen \\ North Dakota State University \\ See next page for additional authors \\ Follow this and additional works at: https://digitalcommons.unl.edu/usdaarsfacpub \\ Part of the Agricultural Science Commons
}

Li, Wenbin; Abad, Jorge A.; French-Monar, Ronald D.; Rascoe, John; Wen, Aimin; Gudmestad, Neil C.; Secor, Gary A.; Lee, Ing-Ming; Duan, Yongping; and Levy, Laurene, "Multiplex real-time PCR for detection, identification and quantification of 'Candidatus Liberibacter solanacearum' in potato plants with zebra chip" (2009). Publications from USDA-ARS / UNL Faculty. 359.

https://digitalcommons.unl.edu/usdaarsfacpub/359

This Article is brought to you for free and open access by the U.S. Department of Agriculture: Agricultural Research Service, Lincoln, Nebraska at DigitalCommons@University of Nebraska - Lincoln. It has been accepted for inclusion in Publications from USDA-ARS / UNL Faculty by an authorized administrator of DigitalCommons@University of Nebraska - Lincoln. 


\section{Authors}

Wenbin Li, Jorge A. Abad, Ronald D. French-Monar, John Rascoe, Aimin Wen, Neil C. Gudmestad, Gary A. Secor, Ing-Ming Lee, Yongping Duan, and Laurene Levy 


\title{
Multiplex real-time PCR for detection, identification and quantification of 'Candidatus Liberibacter solanacearum' in potato plants with zebra chip
}

\author{
Gary A. Secor ${ }^{\mathrm{e}}$, Ing-Ming Lee ${ }^{\mathrm{f}}$, Yongping Duan ${ }^{\mathrm{g}}$, Laurene Levy ${ }^{\mathrm{a}}$ \\ a National Plant Germplasm and Biotechnology Laboratory, USDA-APHIS-PPQ-CPHST, Beltsville, MD 20705, United States \\ b Plant Germplasm Quarantine Program, USDA-APHIS-PPQ-PHP-PSPI, Beltsville, MD 20705, United States \\ ' Plant Pathology and Microbiology, AgriLife Extension, Texas AE'M, Amarillo, TX 79106, United States \\ d Molecular Diagnostic Laboratory, USDA-APHIS-PPQ-PHP, Beltsville, MD 20705, United States \\ e North Dakota State University, Department of Plant Pathology, Fargo, ND 58105, United States \\ ${ }^{\mathrm{f}}$ Molecular Plant Pathology Laboratory, USDA-ARS, Beltsville, MD 20705, United States \\ ${ }^{g}$ U.S. Horticultural Research Laboratory, USDA-ARS, Fort Pierce, FL 34945, United States
}

Wenbin Li ${ }^{\mathrm{a}, *}$, Jorge A. Abad ${ }^{\mathrm{b}}$, Ronald D. French-Monar ${ }^{\mathrm{c}}$, John Rascoe ${ }^{\mathrm{d}}$, Aimin Wen ${ }^{\mathrm{e}}$, Neil C. Gudmestad ${ }^{\mathrm{e}}$,

\section{A R T I C L E I N F O}

\section{Article history:}

Received 30 January 2009

Received in revised form 17 April 2009

Accepted 17 April 2009

Available online 3 May 2009

\section{Keywords:}

Bactericera cockerel

Phloem-limited bacterium

$\alpha$-proteobacteria

\begin{abstract}
A B S T R A C T
The new Liberibacter species, 'Candidatus Liberibacter solanacearum' (Lso) recently associated with potato/ tomato psyllid-transmitted diseases in tomato and capsicum in New Zealand, was found to be consistently associated with a newly emerging potato zebra chip (ZC) disease in Texas and other southwestern states in the USA. A species-specific primer LsoF was developed for both quantitative real-time PCR (qPCR) and conventional PCR (CPCR) to detect and quantify Lso in infected samples. In multiplex qPCR, a plant cytochrome oxidase (COX)-based probe-primer set was used as a positive internal control for host plants, which could be used to reliably access the DNA extraction quality and to normalize qPCR data for accurate quantification of the bacterial populations in environment samples. Neither the qPCR nor the CPCR using the primer and/or probe sets with LsoF reacted with other Liberibacter species infecting citrus or other potato pathogens. The low detection limit of the multiplex qPCR was about 20 copies of the target 16S rDNA templates per reaction for field samples. Lso was readily detected and quantified in various tissues of ZCaffected potato plants collected from fields in Texas. A thorough but uneven colonization of Lso was revealed in various tissues of potato plants. The highest Lso populations were about $3 \times 10^{8}$ genomes/g tissue in the root, which were 3 -order higher than those in the above-ground tissues of potato plants. The Lso bacterial populations were normally distributed across the ZC-affected potato plants collected from fields in Texas, with $60 \%$ of ZC-affected potato plants harboring an average Lso population from $10^{5}$ to $10^{6}$ genomes $/ \mathrm{g}$ tissue, $4 \%$ of plants hosting above $10^{7}$ Lso genomes/g tissue, and $8 \%$ of plants holding below $10^{3}$ Lso genomes/g tissue. The rapid, sensitive, specific and reliable multiplex qPCR showed its potential to become a powerful tool for early detection and quantification of the new Liberibacter species associated with potato ZC, and will be very useful for the potato quarantine programs and seed potato certification programs to ensure the availability of clean seed potato stocks and also for epidemiological studies on the disease.
\end{abstract}

Published by Elsevier B.V.

\section{Introduction}

Zebra chip (ZC) of potato (Soanum tuberosum L.) was first observed in Mexico in 1994 (Secor and Rivera, 2004; Munyaneza et al., 2007). A similar disease, potato purple top, was first recognized in Canada in 1933 (Leyva-López et al., 2002). Potato ZC is defined by a streaking and dark striping in medullary ray tissue of affected potato tubers and in fried, chipped potatoes from which arose its popular name. The

\footnotetext{
* Corresponding author.

E-mail address: Wenbin.Li@aphis.usda.gov (W. Li).
}

disease was found in the United States potatoes in 2000 near Pearsall, Texas, and the Texas side of the Lower Rio Grande Valley, and currently has spread throughout Central America and southwestern U. S states (Gudmestad and Secor, 2007). ZC drastically reduces quality and value of all market classes of potato. Outbreaks of the disease occurred from 2004 to 2006 in Mexico, and in Texas and other U. S. states costing growers and processors on both sides of the border millions of dollars in losses. In isolated instances, ZC has caused entire fields to be abandoned (Gudmestad and Secor, 2007). The disease was recently found in New Zealand (Liefting et al., 2008). ZC symptoms have been observed in many potato cultivars; none of them appears to be resistant (Gudmestad and Secor, 2007). 
Numerous symptoms have been observed in ZC affected plants including plant stunting, leaf scorch and chlorosis, swollen nodes, a 'zigzag' appearance of the upper growth, proliferated auxiliary buds, aerial tubers, browning of the vascular system in the below-ground portions of stalks, enlarged lenticels of the underground stalks, collapsed stolons, brown discoloration of the vascular ring, necrotic flecking of internal tuber tissues, and occasionally streaking of the medullary ray tissues (Gudmestad and Secor, 2007). Most of these symptoms have been observed in plants exhibiting the purple top wilt syndrome associated with the clover proliferation phytoplasma recently found in Washington and Oregon states (Munyaneza et al., 2007), and are similar to, but distinct from, those of net necrosis in potato tubers caused by the phloem-limited potato leaf roll virus.

Potato ZC was observed to be transmitted by the potato/tomato psyllid (Bactericera cockerelli Sulc) that is common and abundant in Southern U. S. and Mexico (Munyaneza et al., 2007). B. cockerelli was first documented in Mexico in 1947, and has been a primary pest of potato, chili pepper (Capsicum spp.), and tomato (Solanum lycopericum) since 1960s (Garzón et al., 1992). It is unknown when the psyllid was introduced into the U. S. The severity of ZC can vary from year to year and within a field, which might be a result of the differences in weather conditions during winter and microclimates on the populations of the vector psyllids. The psyllid was found in greenhouses in Auckland, New Zealand, in May 2006, and soon found established throughout most parts of the nation (Liefting et al., 2008).

Graft transmission of potato ZC to healthy potato indicated that the cause of ZC is a graft transmissible pathogen and not attributed to an abiotic cause such as heat stress (heat necrosis), a psyllid toxin (psyllid yellows) (Richard, 1928), a nutrient deficiency or toxicity, or a combination of these factors (Gudmestad and Secor, 2007). The characteristic of the symptoms described above implies the involvement of a systemic or vascular pathogen, most likely a virus, viroid, prokaryote (bacterium or bacterial-like) or fungus as the causal agent of the disease. Extensive laboratory testing of ZC affected plants has already eliminated a number of potential candidate pathogens such as Ralstonia solanacearum, Serratia marcescens, and many viruses including tomato spotted wilt, various strains of PVY strains, geminiviruses, tobacco rattle, beet western yellows, potato leaf roll and 10 other virus families (Gudmestad and Secor, 2007). ZC-affected potato plants exhibited symptoms similar to those of potato purple top wilt disease found in Washington and Oregon, USA, which was associated by subgroup 16SrVI-A phytoplasma (Lee et al., 2004). However, phytoplasmas were not consistently detected in potato plants or tubers exhibiting ZC symptoms (Munyaneza et al., 2007), suggesting some other pathogen(s) must be involved in ZC. In January 2008, a Liberibacter species designated as 'Candidatus Liberibacter solanacearum' (Lso) (Liefting et al., 2009, in press) was associated with diseases of tomato and capsicum plants in New Zealand (Liefting et al., 2008). These diseases of tomato and capsicum showed very similar symptoms to those reported as "psyllid yellows" (Richard, 1928 ) and to the foliar symptoms described for potato ZC (Liefting et al., in press). In the U.S., the new Liberibacter species was associated, on July 14, 2008, with potato ZC in Texas (Abad et al., 2009; Bech, 2008). The solanaceous liberibacter species was also detected in B. cockerelli collected on tomato plants in Texas and transmitted empirically by the psyllids to induce "psyllid yellows" in tomato and potato plants (Hansen et al., 2008). Although the solanaceous liberibacter species is closely related with species of liberibacter associated with citrus Huanglongbing (Lin et al., 2009), the new Liberibacter species is not associated with the citrus disease nor has it been found in Asian citrus psyllids (Diaphorina citri) (Li et al., 2008b).

To detect the solanaceous Liberibacter species by conventional PCR (CPCR), one forward primer, OA2, was developed (Liefting et al., 2008). The specific primer was paired with the universal reverse primer OI2c that was designed for 'Ca. Liberibacter asiaticus' (Las) and
‘Ca. Liberibacter africanus' (Laf) (Jagoueix et al., 1996). These two species of Liberibacter are associated with two forms of citrus Huanglongbing (HLB) (ex. citrus greening). In addition, the third form of HLB was found associated with ' $\mathrm{Ca}$. Liberibacter americanus' (Lam) in Brazil in 2004 (Teixeira et al., 2005). Real-time quantitative PCR (qPCR) has become the most accurate and sensitive method for detection and quantification of plant pathogens since the first commercial qPCR instrument was available (Heid et al., 1996). The higher detection sensitivity and quantitative power of qPCR was clearly demonstrated for citrus Liberibacter species (Li et al., 2006, 2007, 2008a, 2009). The principle objective of this study was to develop a rapid, sensitive and specific TaqMan real-time PCR assay for detection, identification and quantification of ' $\mathrm{Ca}$. Liberibacter solanacearum' in its host plants. The method can be used to understand the pathway, epidemiology of the disease, for the Germplasm Screening Programs and the Seed Potato Certification program to ensure the availability of clean seed potato.

\section{Materials and methods}

\subsection{Plant materials}

Plant materials of 5-month old ZC suspect potato plants (Fig. 1) were collected from Lubbock County, Texas and stored at $4{ }^{\circ} \mathrm{C}$. Before sampling, the plant materials were washed in tap water and then in distilled water. Materials of individual plants were divided into aboveand below-ground sample groups. In the above-ground group, tissues of leaf midribs and petioles, leaf blades, whole stalk, stalk epidermis, stalk cortices and aerial tubers were separately sampled. Samples of root epidermis, root cortices and tubers were separated from the below-ground group. Lso-infected materials were also collected from potato and tomato plants that were experimentally inoculated with the ZC disease by stalk grafting in a greenhouse (USDA-ARS, Beltsville, Maryland). Similar samples from healthy materials of potato plants were collected as negative controls both from a ZC-free potato farm in Texas and from greenhouse-grown plants of potato (USDA-APHISPPQ, Beltsville, Maryland).

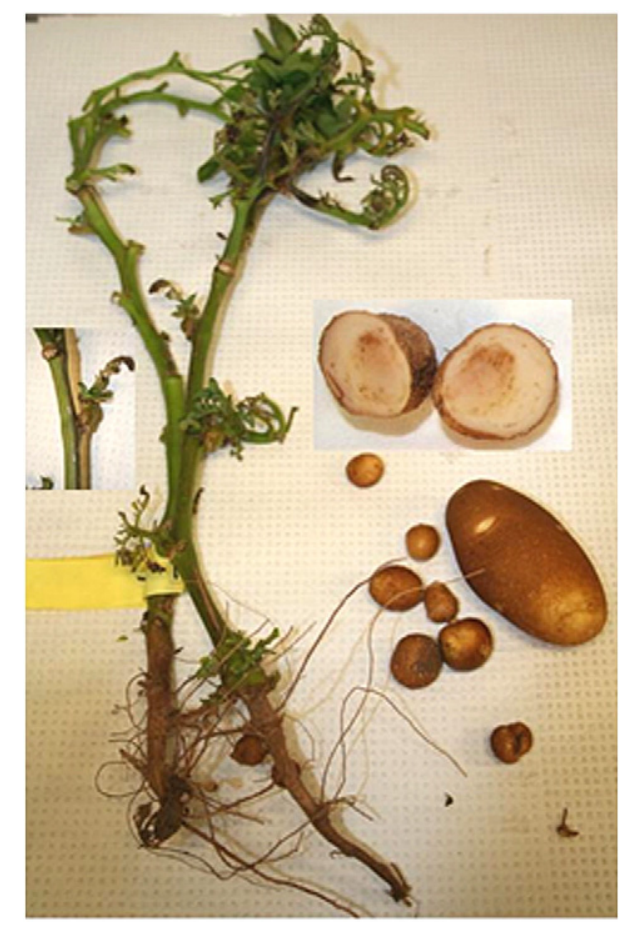

Fig. 1. Typical symptoms of zebra chip on a potato plant collected in the field in Texas. This plant was used in the trial on in-planta distribution of ' $\mathrm{Ca}$. Liberibacter solanacearum'. 


\subsection{DNA extraction}

Total DNA from field and greenhouse samples was isolated using the DNeasy Plant Mini Kit (Qiagen, Valencia, CA), according to the manufacturer's instruction. For study on distribution of ' $\mathrm{Ca}$. Liberibacter solanacearum', three sub-samples of $400 \mathrm{mg}$ from each type of tissues were collected for DNA extraction. For field or greenhouse samples, $100 \mathrm{mg}$ of midribs and petioles was used per extraction. All samples were cut into sections of about $1 \mathrm{~mm}$ wide and homogenized using a FastPrep (MP Biomedical, Solon, Ohio) bead mill as described previously (Li et al., 2006). Sample DNA was eluted with $100 \mu$ l elution buffer of the Qiagen kit. The concentration of total sample DNA (plant + pathogen) present in the extracts was estimated with a NanoDrop spectrophotometer (NanoDrop Technologies, Wilmington, DE, USA).

\subsection{Primer and probe}

One species-specific forward primer LsoF, 5'-GTC GAG CGC TTA TTT TTA ATA GGA-3' was empirically designed at the signature region of the 16S rRNA sequence of 'Ca. Liberibacter solanacearum' (NCBI GenBank accession number EU980389). The design of the forward primer was optimized to be compatible with the Liberibacteruniversal TaqMan probe (HLBp) and reverse primer (HLBr) used for real-time PCR assays (Li et al., 2006), as well as with the reverse primer OI2c employed in conventional PCR testing (Jagoueix et al., 1996). In silico PCR was performed for all the primer-probe and primer-primer combinations by using BLASTn against the NCBI GenBank database to ensure their specificity prior to primer and probe synthesis by the Integrated DNA Technologies, Inc.

\section{4. $16 \mathrm{~S}$ rRNA gene cloning and sequencing}

To establish a standard curve for absolute quantification, a band of 1163 bp was amplified from 16S rDNA of Lso in a field sample from Texas with the newly-designed forward primer LsoF and the reverse primer OI2c (Jagoueix et al., 1996). To obtain the 16S rRNA gene sequence of Lso, these two primers were paired with the 16S rRNAbased universal primers, fD2, rP1 (Weisburg et al., 1991), XF04af and XF04ar (Montero-Astua et al., 2007), in combinations of LsoR/rP1, fD1/OI2c, LsoF/XF04ar and XF04af/OI2c. PCR amplifications were performed using the validated conventional PCR protocol for detection of Liberibacters (Li et al., 2007). The amplification products obtained were cloned into the TOPO TA pCRII vector (Invitrogen) and the plasmids were propagated in the strain Mach1-T1 of E. coli (Invitrogen) and purified using a PureLink Quick Plasmid Miniprep kit (Invitrogen). The 16S rDNA fragments were sequenced in both directions using the M13 forward and reverse primers at the Center for Biosystems Research, DNA Sequencing Facility, University of Maryland, College Park.

\subsection{Standard curves for quantification}

The cloned plasmid with a fragment of 1163 bp from 16S rDNA obtained with the primer set LsoF/OI2c was named pTXZC18. The number of copies of pTXZC18 was estimated using the number of base pairs $(n=5136)$ and the average molecular mass of a base pair in double strand DNA (660 Da), resulting in one copy (molecule) of pTXZC18 calculated to be $5.658 \times 10^{-6} \mathrm{pg}$. The initial concentration of the pTXZC18 standard was adjusted in TE buffer to be $9.92 \times 10^{8}$ copies/ $\mu$ l (Fig. 3). To obtain an absolute standard curve (Fig. 4), 10-fold serial dilutions from the initial concentration of pTXZC18 were prepared in a total DNA extract from midribs and petioles of healthy potato plants. Based on the absolute standard curve determined above, the target DNA copy number of Lso in the DNA extract obtained from the root epidermis of the potato plant showing typical ZC symptoms (Fig. 1 ) was estimated to be $3.62 \times 10^{6}$. To evaluate the low detection limit of real-time PCR for environmental samples using a sample standard curve as described previously (Li et al., 2008a), 10fold serial dilutions of the field DNA extract were prepared also using the total DNA extract from midribs and petioles of healthy potato plants.

\section{6. $P C R$ assays}

Conventional PCR assays were performed in the same standard conditions optimized previously (Li et al., 2007). In brief, the PCR reaction mix contained $1 \times$ PCR buffer, 1 unit of Platinum Taq polymerase (Invitrogen), $2.5 \mathrm{mM} \mathrm{MgCl} 2,200 \mu \mathrm{M}$ each dNTPs, $200 \mu \mathrm{M}$ each primer and $2 \mu \mathrm{l}$ of DNA sample. The PCR amplification was carried out in 1 cycle at $94{ }^{\circ} \mathrm{C}$ for $2 \mathrm{~min}, 35 \mathrm{cycles}$ at $94{ }^{\circ} \mathrm{C}$ for $30 \mathrm{~s}, 62^{\circ} \mathrm{C}$ for $30 \mathrm{~s}$ and $72{ }^{\circ} \mathrm{C}$ for $1 \mathrm{~min}$, and 1 cycle at $72^{\circ} \mathrm{C}$ for $10 \mathrm{~min}$, using a Biometra T3 thermocycler. The PCR products were visualized in 1.0\% agarose gel stained with ethidium bromide. TaqMan real-time PCR assays with the Lso-specific primer-probe set Lso-HLBp-HLBr (Lsopr) and the positive internal control primer-probe set COXfpr (plant mitochondrial cytochrome oxidase) were performed as described previously (Li et al., 2006), using a SmartCycler II (Cepheid, Sunnyvale, CA). The real-time PCR mix contained $1 \mathrm{x}$ PCR buffer, 1 unit of Platinum Taq polymerase (Invitrogen), $6.0 \mathrm{mM} \mathrm{MgCl} 2,240 \mu \mathrm{M}$ each dNTPs, $240 \mu \mathrm{M}$ each primer, $120 \mu \mathrm{M}$ each probe, and $2 \mu \mathrm{l}$ of DNA sample. The real-time PCR program was 1 cycle at $95^{\circ} \mathrm{C}$ for $20 \mathrm{~s}$ with optics off and 40 cycles at $95^{\circ} \mathrm{C}$ for $1 \mathrm{~s}$ with optics off and at $58^{\circ} \mathrm{C}$ for $40 \mathrm{~s}$ with optics on. Reactions for field diagnostic samples were performed in duplicate and those for experimental purposes were done in triplicate. Each diagnostic run contained one negative and one positive control (Table 1).

\subsection{Statistics analysis}

Real-time PCR data were exported from the SmartCycler software version 2.0D (Cepheid, Sunnyvale, CA) for calculation of mean crossing threshold $(\mathrm{Ct})$ values and standard deviations (SDs). Standard linear regressions $(Y=a+b X)$ of the log concentration of the target DNA copies $(Y)$ versus the mean $C t$ values $(X)$ were obtained. PCR amplification efficiency (AE) was calculated from the slopes of the regressions using the equation $\mathrm{AE}=10^{- \text {slope }}-1$ ( $\mathrm{Li}$ et al., 2008a). Before the Ct values of real-time PCR were used for estimating the bacterial population, they were normalized by multiplying with a normalization coefficient $(\mathrm{Nc})$ obtained from their positive internal control reaction. $\mathrm{Nc}=1$-(inCt-MinCt)/MinCt: with the 'inCt' being the $\mathrm{Ct}$ value of the internal control primer-probe set COXfpr for a sample and the 'MinCt' being the mean inCt obtained from all samples. For studies evaluating the bacterial population in various plant tissues, comparisons between types of tissues were made using one-way analysis of variance (ANOVA). When significant, the comparisons were evaluated by two-way ANOVA. Least significant differences were calculated by a means comparison test (Tukey's) using a confidence level of $P=0.05$.

\section{Results}

\subsection{Zebra chip syndrome}

ZC affected potato plants collected from TX exhibited collapsed stalks in addition to showing stunting and auxiliary bud proliferation (Fig. 1). Young leaves were underdeveloped with symptoms such as interveinal chlorosis and scorching. The stalks developed proliferated auxiliary buds on the tips, aerial tubers on the stalks and swollen nodes on the upper growth causing a 'zigzag' appearance. The belowground portions of stalks had a brown vascular system, enlarged lenticels, and collapsed stolons. The tubers were reduced in size and developed necrotic flecking of internal tissues and streaking of the medullary ray. ZC diseased potato plants generally developed very few 
Table 1

Specificity of PCR assays for 'Candidatus Liberibacter solanacearum' in potato plants affected with zebra chip.

\begin{tabular}{|c|c|c|c|c|c|c|c|c|}
\hline \multirow[t]{2}{*}{ Pathogen } & \multirow[t]{2}{*}{ Host } & \multirow[t]{2}{*}{ Provider } & \multirow[t]{2}{*}{ Origin } & \multicolumn{4}{|c|}{ Real-time PCR } & \multirow{2}{*}{$\begin{array}{l}\text { Conventional } \\
\text { PCR (LsoF/OI2c) }\end{array}$} \\
\hline & & & & HLBaspr & HLBafpr & HLBampr & $\overline{\text { Lsopr }}$ & \\
\hline \multicolumn{9}{|l|}{ ‘Ca. Liberibacter solanacearum’ } \\
\hline Strain TX001 & Potato & French-Monar, R & Texas & 0 & 0 & 0 & 20.55 & + \\
\hline Strain TX002 & Potato & French-Monar, R & Texas & 0 & 0 & 0 & 27.42 & + \\
\hline Strain TX003 & Potato & French-Monar, R. & Texas & 0 & 0 & 0 & 30.05 & + \\
\hline Strain TX004 & Potato & French-Monar, R. & Texas & 0 & 0 & 0 & 31.22 & + \\
\hline Strain TX005 & Potato & French-Monar, R. & Texas & 0 & 0 & 0 & 31.24 & + \\
\hline Strain TX006 & Potato & French-Monar, R & Texas & 0 & 0 & 0 & 31.94 & + \\
\hline StrainTX007 & Potato & French-Monar, R & Texas & 0 & 0 & 0 & 32.18 & + \\
\hline StrainTX008 & Potato & French-Monar, R. & Texas & 0 & 0 & 0 & 32.46 & + \\
\hline Strain NTX2005 & Potato & Gudmestad, N. C. & Texas & 0 & 0 & 0 & 32.15 & + \\
\hline Strain NTX2006 & Potato & Gudmestad, N. C. & Texas & 0 & 0 & 0 & 34.26 & + \\
\hline Strain STX2007 & Potato & Gudmestad, N. C. & Texas & 0 & 0 & 0 & 35.20 & - \\
\hline Strain NTX2008 & Potato & Gudmestad, N. C. & Texas & 0 & 0 & 0 & 32.22 & + \\
\hline Strain NE2008a & Potato & Gudmestad, N. C. & Nebraska & 0 & 0 & 0 & 27.16 & + \\
\hline Strain CO2008 & Potato & Gudmestad, N. C. & Colorado & 0 & 0 & 0 & 31.39 & + \\
\hline Strain TXZC2p & Potato & Lee, I.-M. & Greenhouse & 0 & 0 & 0 & 29.17 & + \\
\hline Strain TXZC3p & Potato & Lee, I.-M. & Greenhouse & 0 & 0 & 0 & 29.55 & + \\
\hline Strain ZC8\#1 & Tomato & Lee, I.-M. & Greenhouse & 0 & 0 & 0 & 30.74 & + \\
\hline Strain ZC8\#2 & Tomato & Lee, I.-M. & Greenhouse & 0 & 0 & 0 & 25.25 & + \\
\hline \multicolumn{9}{|l|}{ 'Ca. Liberibacter asiaticus' } \\
\hline Strain FL136 & Citrus & Li, W. & Florida & 25.25 & 37.47 & 0 & 0 & - \\
\hline Strain KIN1 & Citrus & Iwanami, T. & Japan & 26.26 & 38.62 & 0 & 0 & - \\
\hline Strain Las 692 & Citrus & Teixeira, D. C. & Brazil & 25.21 & 37.25 & 0 & 0 & - \\
\hline \multicolumn{9}{|l|}{ 'Ca. Liberibacter africanus' } \\
\hline Strain Letaba & Citrus & Van Vurren, F. & S. Africa & 37.35 & 25.62 & 0 & 0 & - \\
\hline Strain Stellenbosch & Citrus & Van Vurren, F. & S. Africa & 38.12 & 26.08 & 0 & 0 & - \\
\hline Strain ITSC & Citrus & Van Vurren, F. & S. Africa & 38.04 & 24.24 & 0 & 0 & - \\
\hline \multicolumn{9}{|l|}{ 'Ca. Liberibacter americanus' } \\
\hline Lam 974 & Citrus & Teixeira, D. C. & Brazil & 0 & 0 & 22.26 & 0 & - \\
\hline Lam 975 & Citrus & Teixeira, D. C. & Brazil & 0 & 0 & 22.66 & 0 & - \\
\hline Lam 976 & Citrus & Teixeira, D. C. & Brazil & 0 & 0 & 24.62 & 0 & - \\
\hline Potato leaf roll virus & Potato & Gudmestad, N. C. & Unknown & 0 & 0 & 0 & 0 & - \\
\hline Clover proliferation phytoplasma & Potato & Gudmestad, N. C. & Oregon & 0 & 0 & 0 & 0 & - \\
\hline ‘Candidatus Phytoplasma americanum' & Potato & Gudmestad, N. C. & Nebraska & 0 & 0 & 0 & 0 & - \\
\hline Xyella fastidiosa PD strain & Grapevine & Hartung, J. S. & Brazil & 0 & 0 & 0 & 0 & - \\
\hline Xylella fastidiosa CVC strain & Citrus & Hartung, J. S. & California & 0 & 0 & 0 & 0 & - \\
\hline
\end{tabular}

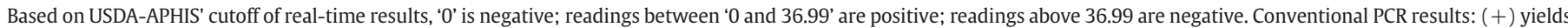
specific a band and $(-)$ dose not yield a specific band.

rootlets. The symptoms observed in this study were nearly identical to those described previously for ZC (Gudmestad and Secor, 2007; Secor et al., 2008).

\subsection{Signature region of Lso $16 S$ rRNA}

PCR amplicons of 1163 bp (Fig. 2) were obtained by conventional PCR using the primer set Lso/OI2c, from DNA extracts obtained from midribs/petioles, whole stalks, stalk epidermises, stalk cortices, root epidermises, root cortices and tubers of the potato plant affected with $\mathrm{ZC}$ in the field in Texas (Fig. 1), as well as from 10 fold dilutions of the original DNA extracts obtained from the leaf blades and aerial tubers

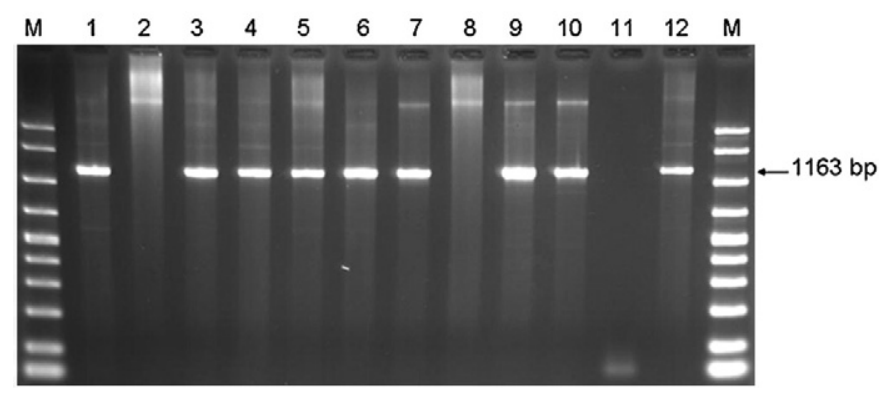

Fig. 2. Detection of 'Ca. L. solanacearum' by conventional PCR in DNA extracts of various tissues: midribs and petioles, leaf blades, whole stalk, stalk epidermis, stalk cortices, root epidermis, root cortices, aerial tubers, small tubers and medium tubers (lanes 1 to 10) of potato plants affected by zebra chip in the field in Texas. Lanes 11 and 12 were no template and positive controls. Marker (M) was the Extra ladder (Invitrogen). of the affected plant. The sequences of all the amplicons of $1163 \mathrm{bp}$ from various tissues above had a 99\% homology with the solanaceous Liberibacter species (NCBI GenBank Accession number EU834130) found associated with diseases of tomato and capsicum described in New Zealand (Liefting et al., 2008). The remainder of the 16S rRNA sequence of Lso was obtained using the primer pairs LsoR/XF04ar and XF04ar/OI2c. The 16S rRNA gene sequence (1503 bp) obtained from the ZC-affected potato plant has been deposited in the GenBank (accession EU980389). Comparative analysis of 16S rRNA gene sequences revealed that the Lso from the ZC-affected potato collected in the field in Texas had a homology of 99\%, 96\%, 96\%, and 94\% with ' $\mathrm{Ca}$. Liberibacter solanacearum' found in New Zealand, Las, Laf and Lam, respectively, and a homology of $99 \%$ with the bacterial symbiont ' $\mathrm{Ca}$. Liberibacter psyllaurous' detected in the potato/tomato psyllids collected in Texas (Hansen et al., 2008). The primer sets fD1/rP1 and $\mathrm{LsoF} / \mathrm{rP} 1$ failed to amplify $16 \mathrm{~S}$ sequences from $\mathrm{ZC}$-affected potato plants collected from Texas. The primer set fD1/OI2c amplified a fragment of about $1.4 \mathrm{~kb}$ from the field DNA sample.

\subsection{Specificity of PCR assays for Lso}

The specificity of the assays with the primer-probe set Lso-HLBp$\mathrm{HLBr}$ (Lsopr) was evaluated in single and multiplex real-time PCR with the positive internal control primer-probe set COXfpr ( $\mathrm{Li}$ et al., 2006), using total DNA extracts from potato plants affected with ZC or other unrelated pathogens including potato leaf roll virus, clover proliferation Phytoplasma, 'Candidatus Phytoplasma americanum', from citrus plants infected with ' $\mathrm{Ca}$. Liberibacter asiaticus', ' $\mathrm{Ca}$. Liberibacter africanus' and 'Ca. Liberibacter americanus', and genomic 

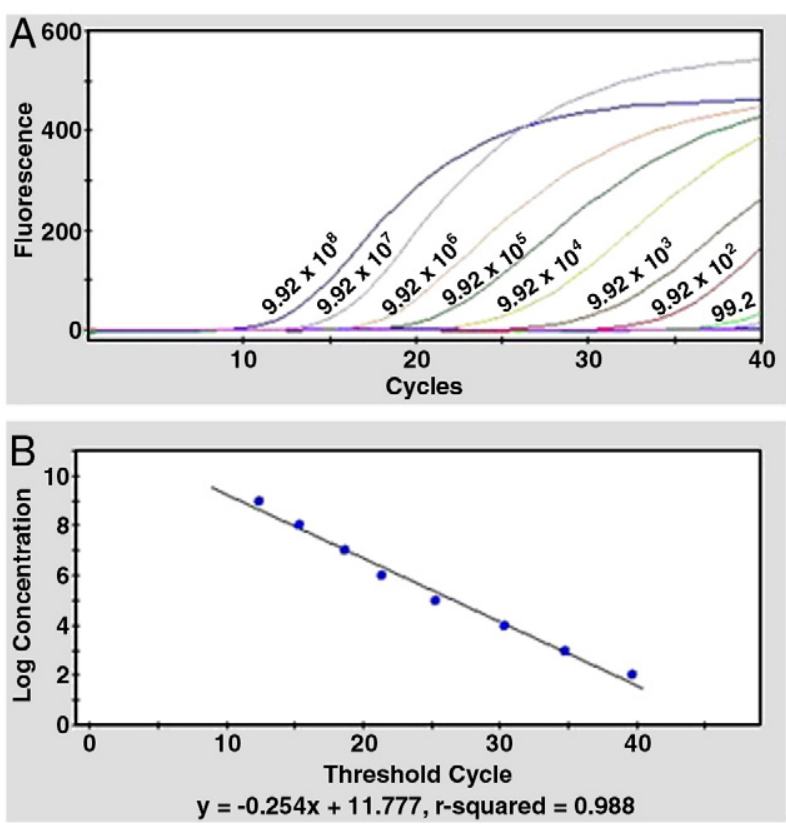

Fig. 3. Sensitivity of the primer-probe set $\mathrm{LsoR} / \mathrm{HLBp} / \mathrm{HLBr}$ specific to ' $\mathrm{Ca}$. $\mathrm{L}$. solanacearum' in multiplex real-time PCR with the positive internal control primerprobe set COXfpr. The template plasmid pTXZC18 DNA diluted in a DNA extract from 5month old healthy potato plants was used to establish a linear regression for absolute quantification: real-time PCR optics graph for 'Ca. L. solanacearum' (A) and standard curve for absolute quantification of ' $\mathrm{Ca}$. L. solanacearum' (B).

DNA from pure cultures of Xylella fastidiosa (Table 1). The assay with Lsopr yielded positive results only from DNA samples infected with Lso. Negative results were obtained for samples infected with other potato pathogens or the three Liberibacter species in citrus evaluated. None of the real-time PCR assays using HLBaspr, HLBafpr or HLBampr specific to citrus Liberibacter species reacted with any DNA samples infected with Lso. The specificity of Lsopr was retained in the multiplex real-time PCR with the positive internal control primerprobe set COXfpr. As expected, the conventional PCR primer set LsoF/ OI2c demonstrated the same specificity for Lso as the real-time PCR primer-probe set Lsopr. Neither the multiplex real-time PCR assays nor the conventional PCR tests for Lso gave any false positive results for 14 DNA extracts obtained from uninfected greenhouse-grown potato plants in Beltsville, Maryland and 50 DNA samples extracted from putative healthy potato plants grown in the field in Texas. In addition, Lso was detected in DNA extracts obtained from ZC-affected potato plants collected in Texas in 2005, 2006 and 2007, in Nebraska in 2008, and Colorado in 2008 (Table 1). Unfortunately, DNA samples of 'Ca. Liberibacter psyllaurous' were not available to us for evaluation, because only limited DNA extracts were obtained from potato/tomato psyllids infected with this Liberibacter (Hansen et al., 2008) and DNA extraction from psyllids is sample-destructive. However, ' $\mathrm{Ca}$. Liberibacter psyllaurous' should be detected by both real-time and conventional PCR assays with the forward primer LsoF, because its 16S rRNA sequence (EU812557) has perfect priming sites not only for LsoF but also for all the reverse primer OI2c, $\mathrm{HLBr}$ and the probe HLBp evaluated in this study.

\subsection{Sensitivity of PCR assays for Lso}

The low detection limit (LDL) of the multiplex real-time PCR with Lsopr and COXfpr was about 10 copies of pTXZC18 per reaction when the plasmid DNA was diluted in water, consistent to those of the absolute standard curves based on plasmid DNA in water for other pathogens (Li et al., 2007; Palaniappan et al., 2005). However, the LDL of the assay with Lsopr was about 100 copies of pTXZC18 per reaction when the plasmid DNA was diluted in the DNA extract complex from healthy potato plants (Fig. 3). Based on the absolute standard curve, the template concentration of Lso 16s rDNA in a DNA extract obtained from the root epidermis of the potato plant affected with ZC (Fig. 1) was estimated to be $3.62 \times 10^{6}$. To obtain a sample standard curve to be used for accurate quantification of the bacterium in plant materials, 10 -fold serial dilutions of the environmental DNA sample were made in the DNA extract complex from healthy potato plants (Fig. 4A and B). According to the sample standard curve, the LDL of the real-time PCR with the primer-probe set Lsopr multiplexed with COXfpr was about 20 copies of the 16S rDNA templates of the bacterium for environmental samples. The amplification efficiency (AE) of the multiplex real-time PCR was $90.99 \%$ for the bacterium in the affected plants of potato.

As shown in Fig. 4B and C, the TaqMan real-time multiplex PCR was about 10 fold more sensitive than the conventional PCR with the primer set Lso/OI2c for Lso detection in plant materials. The conventional PCR using the primer set Lso/OI2c developed in this study was additionally 10 fold more sensitive than the conventional PCR assays using OA2/OI2c (Liefting et al., 2008) for Lso detection in plant materials in our optimized PCR conditions. Among 50 DNA samples extracted from individual potato plants affected with ZC in the field in Texas (Fig. 6), 46 (92\%) tested positive for Lso using the real-time multiplex PCR; 23 (46\%) tested positive using the conventional PCR with the primer set Lso/OI2c; and 20 (40\%) tested positive using the conventional PCR with the primer set OA2/OI2c. Samples
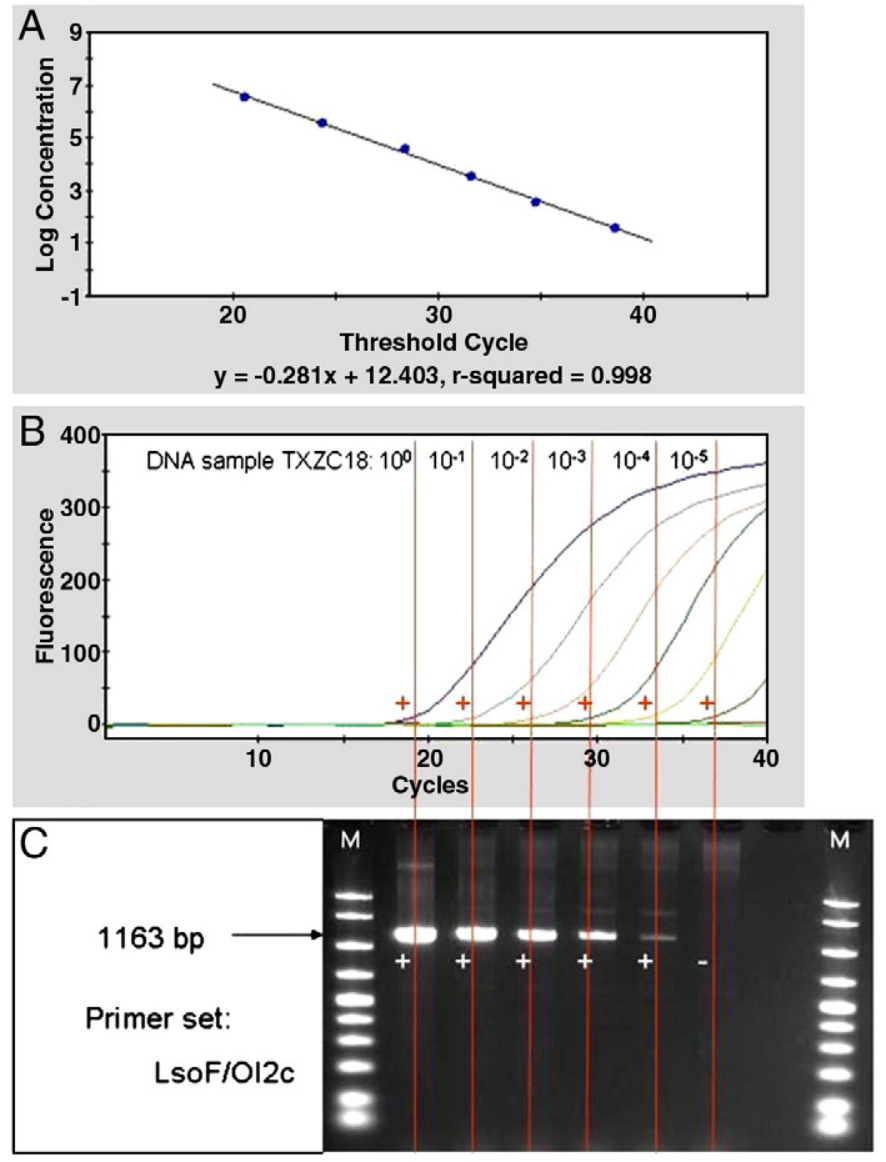

Fig. 4. Low detection limit of primer-probe set LsoR/HLBp/HLBr specific to 'Ca. L. solanacearum' in multiplex real-time PCR with the positive internal control primerprobe set COXfpr. Templates were serial dilutions of an environmental DNA sample extracted from a ZC symptomatic potato plant grown in Texas: sample standard curve for quantification of 'Ca. L. solanacearum' in real samples (A); real-time PCR optics graph (B) and conventional PCR gel (C) for 'Ca. L. solanacearum' in sample dilutions. The starting concentration in the original field sample was estimated to be $3.62 \times 10^{6}$ based on the absolute standard curve in Fig. 3. 
with typical ZC symptoms tested always positive for Lso by qPCR. Lso was also detected in asymptomatic materials of ZC-infected potato plants collected in the field.

\subsection{Uneven in planta distribution of Lso}

Lso was detected and quantified by the real-time multiplex PCR using Lsopr and COXfpr in all tissue types of the affected potato plants examined (Fig. 5). The bacterium was also detected by conventional PCR assays in all the tissues of potato plants, although there was complete inhibition of the amplification in the conventional PCR in DNA extracts from leaf blades and aerial tubers (Fig. 2). Based on the sample standard curve (Fig. 4) and three 16S rRNA operons per genome (or per bacterial cell) (Duan et al., in press), the Lso populations in ZC-affected potato plants were estimated in genome/ $\mathrm{g}$ tissue and no significant differences in the bacterial populations among the aerial parts and tubers were observed. However, the bacterial population was significantly lower in stalks than other tissues above ground. The Lso populations in root epidermis and root cortices were approximately 3-order higher than in all other tissue types of potato plants evaluated. The highest bacterial population was $3 \times 10^{8}$ genome equivalents per gram of fresh tissues in potato root while the lowest Lso population was $1.2 \times 10^{4}$ genome equivalents per gram of fresh 'whole stalk'. On average, each type of other tissues contained $1-5 \times 10^{5}$ genome equivalents per gram of tissues sampled. The mean populations of Lso varied over 3 orders of magnitude among the tissues of ZC infected potato plants used in this study.

\subsection{Distribution of Lso populations in the field}

To study the population dynamics of Lso associated with potato ZC, one group of $50 \mathrm{ZC}$ suspect or symptomatic potato plants collected in the field in Lubbock County of Texas were used. The COXfpr targeting at the host plant DNA of potato yielded stable $\mathrm{Ct}$ values of around 22.00 for the DNA extracts from all the plant samples, indicating an overall high quality of DNA extraction. As shown in Fig. 6, the Lso populations complied with a normal distribution cross the ZC-affected potato plants (Fig. 6). About $60 \%$ of plants had Lso populations from $10^{5}$ to $10^{6}$ genomes per gram of fresh midribs and petioles. Around $10 \%$ of plants had bacterial populations of $10^{4}$ genomes per gram of tissue. Approximate $8 \%$ of plants hosted no Lso or Lso populations less than $10^{4}$ genomes per gram of tissue. Only $18 \%$ of plants harbored Lso populations higher than $10^{6}$ genomes per gram of tissue. The Lso populations were about $10^{5}$ genomes per gram of fresh midribs and petioles in most of the greenhouse-grown potato plants experimen-

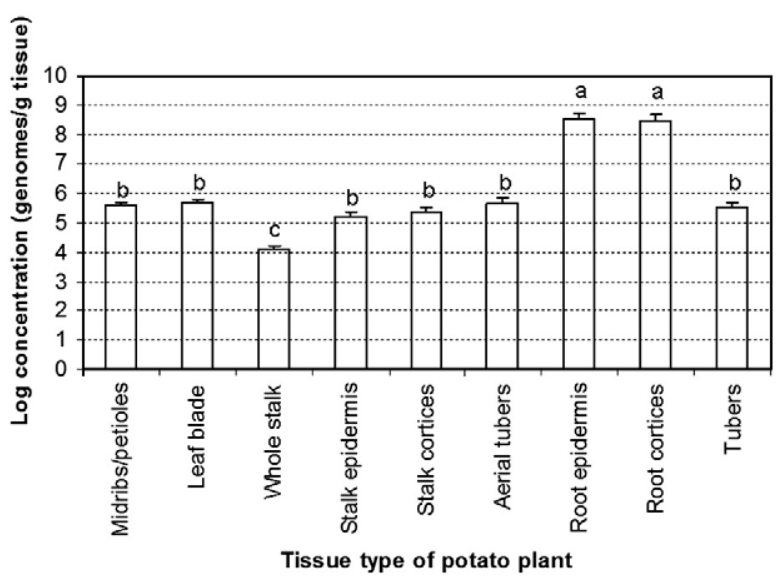

Fig. 5. Quantitative distribution of 'Ca. Liberibacter solanacearum' in various tissues of an environmental DNA sample extracted from a ZC symptomatic potato plant grown in Texas. Bacterial log populations with the same letter on their histogram bars are not significantly different $(P=0.05)$.

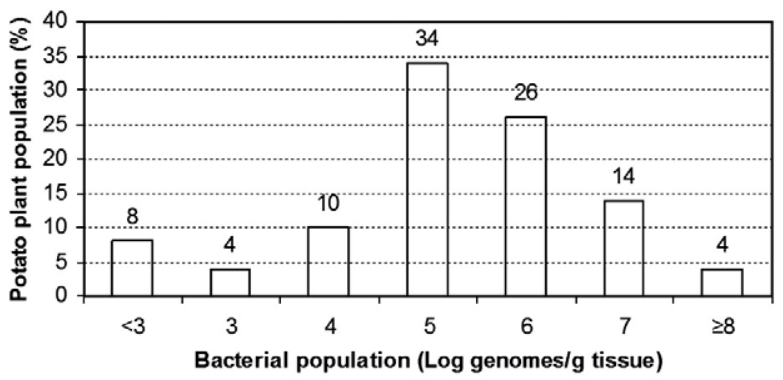

Fig. 6. Population dynamics of 'Ca. Liberibacter solanacearum' in a potato plantation in Texas. One group of $50 \mathrm{ZC}$ suspect or symptomatic potato plants were collected for the study in the field in Lubbock county of Texas. DNA was obtained from midribs and petioles of each plant.

tally inoculated by grafting. However, the titers of the bacterium were usually higher (above $10^{6}$ genomes per gram of fresh midribs and petioles) in greenhouse-grown tomato plants inoculated with Lso by grafting ZC-affected potato stalks.

\section{Discussion}

The accurate detection of plant pathogens is of paramount importance for the timely implementation of disease management and eradication strategies. ZC defied typical diagnostic technologies that would point to known plant pathogens, as the cause of the disease had remained unknown until the disease it was recently associated with ' $\mathrm{Ca}$. Liberibacter solanacearum'. In this study, the Lsospecific primer (LsoF) was designed at the species signature region of the bacterial 16S rRNA sequence. LsoF was compatible in the conventional PCR reaction with the reverse primer OI2c universal to 'Ca. Liberibacter asiaticus' and ' $\mathrm{Ca}$. Liberibacter africanus' (Jagoueix et al., 1996). The conventional PCR with LsoF/OI2c yielded a specific band of 1163 bp from potato and tomato samples infected with Lso. LsoF primer was successfully used together with the genus-universal TaqMan probe HLBp and reverse primer $\mathrm{HLBr}$ in a real-time PCR assay multiplexed with the positive internal control probe-primer set COXfpr (Li et al., 2006). The low detection limit of the real-time multiplex PCR was about 20 copies of Lso 16S rDNA per reaction for environmental samples. This low detection limit showed that the realtime multiplex PCR was at least 10 - to 100 -fold more sensitive than the conventional PCR assays, consistent to the previous comparison between real-time and conventional PCR assays for the citrus Liberibacters (Li et al., 2007). The real-time PCR assay also demonstrated a high PCR amplification efficiency (over 90\%) for environmental DNA or plant samples of potato and tomato. In addition, the positive internal control could be readily used to check the DNA extraction quality from ZC-affected plant materials, and reliably employed in normalization of real-time PCR data for accurate quantification of the bacterial populations in a range of DNA or plant samples from various environments. The real-time multiplex PCR assay developed in this study showed potential to become a valuable tool for early detection, identification and quantification of 'Ca. Liberibacter solanacearum' in ZC-affected plants. Additionally, the specificity of this primer-probe set permits the differentiation of ZC potatoes associated with ' $\mathrm{Ca}$. Liberibacter solanacearum' from potatoes infected with 'Ca. Phytoplasma americanum' (Lee et al., 2006), that should allow for better epidemiological studies to be conducted.

The populations of ' $\mathrm{Ca}$. Liberibacter solanacearum' in potato plants affected with ZC in the field were on average low at about $10^{5}$ genomes per gram of tissues (Fig. 5), which was at least 1,000-factor lower than that of ' $\mathrm{Ca}$. Libeirbacter asiaticus' in leaf midribs of citrus (Li et al., 2009). This might be due to a short growing season of potato plants, which is usually four months from planting to harvesting in Texas. That may not be an ample time for the fastidious bacterium to 
reach its population peak in the host plants. However, the bacterium could thoroughly colonize the entire plants of potato during the short growing season, and cause foliar symptoms on potato plants after flowering, about 40 days of vegetative growing after planting in the field in Texas. In greenhouse conditions, the Lso populations were around $10^{5}$ genomes per gram of above-ground tissues in experimentally inoculated potato plants evaluated in this study, although typical ZC foliar symptoms developed on most potato plants less than one month post-inoculation. The low titers of the bacterium in the aboveground portions of potato plants were consistent with difficulty for its detection without DNA amplification. The Lso bacterium could not consistently be detected either in greenhouse- or field-grown plants infected by potato ZC by the conventional PCR assays in this study, because the bacterial population levels were on the border line of the conventional PCR detection methods. Surprisingly, the Lso populations in potato root tissues were 3-order higher than those in the above-ground tissues. Spiroplasma kunkelli, like Lso, an insect transmitted and phloem limited bacterium causing corn stunt disease, also had its population over 10 -fold higher in distal root sections than in above-ground portions of the plant during the early stage of infection (Davis et al., 1972).

'Ca. Liberibacter solanacearum' was readily detected by the realtime PCR (Fig. 5), in all 9 tissue types of potato plants affected with ZC in the field in Texas, and in 7 of 9 tissue types of the plants by the conventional PCR (Fig. 2). The bacterium was further detected by the conventional PCR in 10 fold dilutions of the 2 DNA extracts (from leaf blades and aerial tubers, respectively) for which the conventional PCR may have failed probably due to PCR inhibitors from the potato tissues. These two DNA extracts were more highly pigmented than other DNA extracts. The difference in amplification success between the real-time and the conventional PCR was consistent with previous observations that real-time PCR is less vulnerable to PCR inhibition than conventional PCR ( $\mathrm{Li}$ et al., 2006). If the conventional PCR is the only assay for Lso diagnosis in potato plants, it is reasonable to suggest retesting with 10 fold DNA dilutions, only for the DNA extracts which test negative with their original extracts. Since the conventional PCR is not as sensitive as the real-time PCR (Fig. 4), and since the Lso populations observed in this study were generally low in almost all kinds of tissues except for root tissues of ZC-affected plants of potato (Figs. 5 and 6), diluting DNA extracts could result in the conventional PCR generating more false negative results. Our data do not suggest the need for DNA dilutions in the real-time PCR assays, because of the low titers of the bacterium in various tissue types of potato plants (Fig. 5). For most of the DNA extracts, real-time PCR Ct values between 30 and 35 were obtained from midribs and petioles of environmental samples (Fig. 6). Diluting DNA samples will only lead to an increase in rates of false negative results in the real-time PCR assays.

In summary, the characteristics of the population dynamics of Lso in ZC affected plants of potato and the assay performance of the realtime and the conventional PCR methods described above will throw light on the etiological, pathological and epidemiological studies of the potato zebra chip disease in the future.

\section{References}

Abad, J.A., Bandla, M., French-Monar, R.D., Liefting, L.W., Clover, G.R.G., 2009. First report of the detection of 'Candidatus Liberibacter' species in zebra chip (ZC) disease infected potato plants in the United States. Plant Dis. 93, 108.

Bech, R.A., 2008. Candidatus Liberibacter spp. as putative causal agent of zebra chip of potatoes. USDA-APHIS, SPRO DA 2008-32. July 14, 2008

Davis, R.E., Whutecomb, R.F., Chen, T.A., Granados, R.R., 1972. Current status of the aetiology of corn stunt disease. Pathogens Mycoplasmas. Elsevier, Amsterdam.

Duan, Y., Zhou, L., Hall, D.G., Li, W., Doddapaneni, H., Lin, H., Liu, L., Gabriel, D.W., Vahling, C.M., Williams, K., Dickerman, A., and Tim Gottwald, T. in press. Complete genome sequence of citrus huanglongbing bacterium, 'Candidatus Liberibacter asiaticus' obtained through metagenomics. Mol. Plant-Microbe Interact.

Garzón, T.J.A., Beverra, F.A., Marín, A., Mejía, A.C.Y., Byerly, M.K.F., 1992. Manejo integrado de la enfermedad " Permanente del tomate " (Lycopersicon lycopersicum Karst ex FawII Mill.), en el Bajío. In: Urías, C., Rodríguez, R., y Alejandre, T. (Eds.), Afidos como vectores de virus em México. Colegio de Postgraduados, Centro de Pitopatología. Vol.

Gudmestad, N.C., Secor, G.A., 2007. Zebra chip: a new disease of potato. Nebr. Potato Eyes 19 (1), 1-4

Hansen, A.K., Trumble, J.T., Stouthamer, R., Paine, T.D., 2008. New Huanglongbing (HLB) Candidatus species, 'C. Liberibacter solanacearum', found to infect tomato and potato is vectored by the psyllid Bactericerca cockerelli (Sulc). Appl. Environ. Microbiol. 5862-5865.

Heid, C.A., Stevens, J.M., Livak, K.L., Williams, P.M., 1996. Real-time quantitative PCR. Genome Res. 6, 986-994.

Jagoueix, S., Bové, J.M., Garnier, M., 1996. PCR detection of the two 'Candidatus Liberobacter species' associated with greening disease of citrus. Mol. Cell. Probes $10,43-50$.

Lee, I.-M., Bottner, K.D., Munyaneza, J.E., Secor, G.A., Gudmestad, N.C., 2004. Clover proliferation group (16SrVI) subgroup A (16SrVI-A) phytoplasma is a probable causal agent of potato purple top disease in Washington and Oregon. Plant Dis. 88, 429.

Lee, I.-M., Bottner, K.D., Secor, G., Rivera-Varas, V., 2006. 'Candidatus Phytoplasma americanum', a phytoplasma associated with a potato purple top wilt disease complex. Int. J. Syst. Evol. Microbiol. 56, 1593-1597.

Leyva-López, N.E., Ochoa-Sábchez, J.C., Leal-Klevezas, D.S., Martínez-Soriano, J.P., 2002. Multiple phytoplasmas associated with potato diseases in Mexico. Can. J. Microbiol. 48, 1062-1068.

Li, W. Hartung, J.S Levy, L, 2006. Quantitative real-time PCR for detection and identification of 'Candidatus Liberibacter species' associated with citrus huanglongbing. J. Microbiol. Methods 66, 104-115

Li, W., Hartung, J.S., Levy, L., 2007. Evaluation of DNA amplification methods for improved detection of 'Candidatus Liberibacter species' associated with citrus huanglongbing. Plant Dis. 91, 51-58.

Li, W., Li, D., Twieg, E., Hartung, J.S., Levy, L., 2008a. Optimized quantification of unculturable 'Candidatus Liberibacter sp.' in host plants using real-time PCR. Plant Dis. 92, 854-861.

Li, W., Abad, J.A., Levy, L., 2008b. Candidatus Liberibacter solanacearum' associated with zebra chip of potato is not associated with citrus huanglongbing and is absent in Asian citrus psyllids. Proc. of Int. Research Conf. on Huanglongbing. Orland, FL, p. 168

Li, W., Levy, L., Hartung, J.S., 2009. Quantitative distribution of 'Candidatus Liberibacter asiaticus' in citrus plants with citrus huanglongbing. Phytopythology 99, 139-144.

Liefting, L.W., Sutherland, P.W., Ward, L.I., Paice, K.L., Weir, B.S., Clover, G.R.G., 2008. A new 'Candidatus Liberibacter' species associated with Solanaceous crops. Plant Dis. 92, 1588.

Liefting, L.W., Sutherland, P.W., Ward, L.I., Paice, K.L., Weir, B.S., Clover, G.R.G., 2009. A new 'Candidatus Liberibacter' species associated with diseases of solanacerous crops. Plant Dis. 93, 208-214.

Liefting, L.W., Weir, B.S., Pennycook, S.R., and Clover, G.R.G. in press. 'Candidatus Liberibacter solanacearum', a liberibacter associated with plants in the family Solanaceae. Int. J. Syst. Evol. Microbiol.

Lin, H., Doddapaneni, H., Munyaneza, J.E., Civerolo, E.L., Sengoda, V.G., Buchman, J.L. Stenger, D.C., 2009. Molecular characterization and phylogenetic analysis of $16 \mathrm{~S}$ rRNA from a new 'Candidatus Liberibacter' strain associated with zebra chip of potato (Solanum tuberosum L.) and the potato psyllid (Bactericera cockerelli Sulc.). J. Plant Pathol. 91, 215-219.

Montero-Astua, M., Hartung, J.S., Aguilar, E., Chacon, C., Li, W., Albertazzi, F.J., Rivera, C., 2007. Genetic diversity of Xylella fastidiosa from Costa Rica, São Paulo and United States of America. Phytopathology 97, 1338-1347.

Munyaneza, J.Z., Crosslin, J.M. Upton, J.E., 2007. Association of Bactericera cockerelli (Homoptera Psyllidae) with zebra chip, a new potato disease in Southwestern United States and Mexico. J. Econ. Entomol. 100, 656-663.

Palaniappan, R.U.M., Chang, Y.F., Chang, C.F., Pan, M.J., Yang, C.W., Harpending, P. McDonouhg, S.P., Dubovi, E., Divers, T., Qu, J., Roe, B., 2005. Evaluation of lig-based conventional and real-time PCR for detection of pathogenic leptospires. Mol. Cell. Probes 19, 111-117.

Richard, B.L., 1928. A new and destructive disease of the potato in Utah and its relation to potato psylla. Phytopathology 18, 140-141.

Secor, G.A., Rivera, V.V., 2004. Emerging diseases of cultivated potato and their impact on Latin America. Rev. Latinoam. Papa 1,1-8 (Suppl.).

Secor, G.A., Rivera, V.V., Rengifo, J., De Boer, S.H., Lee, I.-M., Gudmestad, N.C., 2008. Zebra chip: a new disease of potato. Am. J. Potato Res. 85, 29.

Teixeira, D.C., Ayres, A.J., Kitajima, E.W., Danet, L., Jagoueix-Eveillard, S., Saillard, C., Bové, J.M., 2005. First report of a huanglongbing-like disease of citrus in São Paulo, Brazil, and association of a new Liberibacter species, 'Candidatus Liberibacter americanus' with the disease. Plant Dis. 89, 107.

Weisburg, W.G., Barns, S.M., Pelletier, D.A., Lane, D.J., 1991. 16S ribosomal DNA amplification for phylogenetic study. J. Bacteriol. 173, 697-703. 